JTE

Journal of Teaching English

Volume 5 No. 3,2020

e-ISSN: 2548-6810

\title{
THE EFFECT OF USING SCIENTIFIC APPROACH ON STUDENTS' VOCABULARY ACHIEVEMENT AT GRADE EIGHT OF SMP MUHAMMADIYAH KENDARI
}

\section{DEMAULID, Siam, Wa Ode Fatmawati}

Halu Oleo University, Indonesia

\begin{tabular}{l}
\multicolumn{1}{c}{ ARTICLE INFO } \\
\hline Keywords: \\
Scientifics Approach, \\
Vocabulary \\
Achievement \\
How to cite: \\
DOI: \\
\hline
\end{tabular}

\begin{abstract}
This study was conducted to investigate the effect of using Scientifics Approach on Students' vocabulary achievement at grade eight of SMP Muhammadiyah Kendari. The research question of this study was "Is there any significant effect in using of Scientific Approach to increase the students' vocabulary achievement at grade eight of SMP Muhammadiyah Kendari?" The objective of the study was to find out data and information whether there is a significant effect in using of Scientific Approach to increase the students' vocabulary achievement at grade eight of SMP Muhammadiyah Kendari. The design of study was a pre-experimental design. The sample of this study was taken by using random sampling which consisted of 30 students. The instrument of this study was vocabulary test which consisted 40 items. The result of the study showed that there was a significant effect in teaching vocabulary through the use of Scientific Approach at grade eight of SMP Muhammadiyah Kendari. The average of students' vocabulary achievement before using Scientific Approach was 4.99 which is in low category. Meanwhile, the students' vocabulary achievement after using Scientific Approach was 7.59 which is in high category. The result of hypothesis testing proves that $\mathrm{t}$-test $=25.36$ was higher than $\mathrm{t}$-table $=2.04$. This finding shows that in teaching vocabulary by using Scientific Approach improve students' vocabulary achievement at grade eight of SMP Muhammadiyah Kendari.
\end{abstract}

\section{INTRODUCTION}

The English curriculum of SMP Muhammadiyah Kendari in academic year 2017/2018 which is called in use Kurikulum Tingkat Satuan Pendidikan (KTSP) states that there are four language skills that should be mastered by students namely; 
listening, speaking, reading, and writing. In applying these four language skills, the students have to have vocabulary knowledge. This is relevant to Edwards (2006:177) that the students who are less in vocabulary, they usually have difficulty in writing their own idea, unable to speak English and difficult in understanding the text. In addition, the students usually read slowly because they don't understand many words or have to stop and look up in dictionary. It indicates that vocabulary is very significant role for students or learners in understanding the four skills of the language. It is because by having vocabulary knowledge, the learners can communicate well and can facilitate the comprehension of a text that they read. The learners can also express their ideas in writing and speaking.

It is in contrary to students of grade eight of SMP Muhmmadiyah Kendari in academic year 2017/2018 that they are still difficult in applying the four language skills of English, because they are lack of vocabulary mastery. This is stated by Sudarmon (the English teacher of SMP Muhammadiyah Kendari that there are still many students of junior high school who are facing difficulty in learning English, mainly: (1) comprehend the content of reading text, (2) express idea both in orally and written form, (3) students cannot communicate in English. The main cause of these problems is students' lack of vocabulary, (an informal interview with Sudarmon, S.Pd, English teacher of SMP Muhammadiyah Kendari on $4^{\text {thd }}$ February 2018). This statement is also supported by researcher's observation on $4^{\text {th }}$ February 2018 at SMP Muhammadiyah Kendari that the researcher found that most of students are still poor of vocabulary and they still depend on teacher's help and dictionary when they get unfamiliar words. On the other hand, the ability of students on vocabulary development is still poor. The researcher tried to give the text to students and asked the students to mention the meaning of each word on the text. The result was the students difficult to comprehend the text because they did not know almost the meaning of each word on the text.

Based on the facts above, the researcher may say that it needs suitable approach in teaching vocabulary in order to improve the students' vocabulary achievement of grade eight of SMP Muhammadiyah Kendari in academic year 2017/2018. In this case, the researcher supposes"Scientific Approach" for solution 
of students' lack of vocabulary. The researcher expected that by using this approach will help students to understand and using the words and improve students' vocabulary knowledge.

\section{Research Question}

Based on the description above, the researcher formulated a research question as follow "Is there any significant effect of using of Scientific Approach to improve the students' vocabulary achievement at the grade eight of SMP Muhammadiyah Kendari?

\section{The Objective of the Study}

The objective of this research was to find out the data and information whether there is a significant effect in using of Scientific Approach on increasing students' vocabulary achievement at the grade eight of SMP Muhammadiyah Kendari.

\section{Hypothesis}

Based on description on the background, the hypothesis of this research as follows:

"There is a significant effect in teaching vocabulary under Scientific Approach on students vocabulary achievement at the grade eight of SMP Muhammadiyah Kendari.

\section{LITERATURE REVIEW}

\section{Vocabulary}

\section{The Definition of Vocabulary}

The definition of vocabulary that is defined Steven Stahl $(2005: 132)$ who states that "vocabulary knowledge is knowledge; the knowledge of a word not only implies a definition, but also implies how that word fits into the world."

Meanwhile, Harimurti Kridalaksana as cited by Mido (2012: 17) states that vocabulary is a component of language that maintains all of information about meaning and using word in language. According to Websters Ninth Collegiate Dictionary as cited by Mido (2012:17) states that vocabulary are (1) a list or collection of words and phrase usually alphabetically arranged and explained or defined; (2) a sum or stock of words employed by a language group individual or work or in a field of knowledge; and (3) a list or collection of terms or codes available for use. 


\section{The Importance of Vocabulary Knowledge}

Rupley, Logan \& Nichol, in Kasiani 2007:27 who states that vocabulary knowledge is important that possessed by students. The vocabulary knowledge is important because it encompasses all the words we must know to access our background knowledge, express our ideas and communicate effectively, and learn about new concept. "Vocabulary is the glue that holds stories, ideas and contents together making comprehension accessible for children”, (Kasiani, 2007.28).

By importance of vocabulary mastery, teacher must provide to the students with opportunities to build word skills. According to Rupley, Logan \& Nichol, in Kasiani (2007), One way to do this is to pre-teach about the techniques of teaching vocabularies, such as semantic gradient technique grasp concepts that contain terms with which they may be unfamiliar. Putting emphasis on root words, prefixes, and suffixes assist students in morphemic analysis, which combines this knowledge with the context to figure out a new word's meaning. Furhuremore The importance of vocabulary can make a difference in their ability to succeed in school and work.

\section{Technique of Teaching Vocabulary}

Learners acquire vocabulary in various ways. Students are exposed to a lot of new vocabulary during lessons: by the teacher, by texts or other materials they work with. All of these vocabularies are automatically absorbed (Harmer 1993:159). Besides this incidental acquisition, there are "pre-planned lesson stages in which learners are taught pre-selected vocabulary items" (Thornbury 2004:75). Various techniques and activities are aimed directly at learning vocabulary, which is usually put into sets of somehow related words, often by topic or meaning.

Thornbury (2004: 93) states that one of the important roles of the language teacher is to help their students find the easiest way of conveying new information into the already existing system of the mental lexicon. McCarty (1992:17) suggests that before presenting new language, pre teaching activities might be beneficial "to activate existing knowledge to make the encounter with new words more meaningful."(McCarthy 1992:108) Pre-teaching activities often arouse students' attention and desire to explore a particular topic or subject in greater detail. 
Both McCarthy (1992:110) and Thornbury (2004:76) state that there are two general possibilities of arranging vocabulary presentation. First, The teacher provides the learners with the meaning of the words and then progresses to introduction of their forms or vice versa - the form is introduced first, followed up with illustration of the meaning. Second, forms are often presented in text or another form of context and students are encouraged to discover meanings and other properties of words themselves. This type of activity is called the discovery technique.

In teaching vocabulary, some researchers suggested using visual media such as realia, pictures, film, mind mapping, flashcard, and other visual media as technique that can be used (Kasiani, 2007:160). He adds the explaination about the example of visual media as follow:

a. Realia: it is useful for teaching meaning of words or for stimulating students' activity. For beginners, especially children, teacher sometimes come to the classroom by bringing plastic fruits, cardboard clock faces, or two telephones to stimulate phone conversation.

b. Pictures: pictures are extremely useful for a variety of communication activities, particularly where these have a game-like feel, such as describe and draw activities, where one student describes a picture (which has given them) and a partner has to draw the same picture without looking the original.

c. Film: the idea of using films since they are colorful, attractive, enjoyable, and the character in the films produce sounds which can be imitated by children.

d. Mind-mapping: it is a diagram which is used to represent words, ideas, thought, numbers in a simpler form which connects all the ideas together and hence will be easier for the viewers to quickly grasp the idea. Besides, this activity helps bring into consciousness relationship among words in a text and helps deepen understanding by creating associative networks for words.

\section{Aspects in Teaching Vocabulary}

According to Ur (1996:120), there are some aspects in teaching vocabulary. Those aspects are: (a) Pronunciation and spelling. Correct pronunciation is very important since it will lead someone to a successful communication or fail him. When 
someone constantly mispronounces some sounds, it will make other people misunderstand what he/she says or get confused. (b) Grammar. Teaching of grammar is necessary at one stage to establish and automates the new language on the learner's memory so that when needed they are easily retrieved. (c) Collocation. Collocation is one part should be pay attention by the teacher in presenting of vocabulary, particularly in its relation for developing of students' English vocabulary. (d) Aspect of meaning. The meaning aspect can also be useful in teaching vocabulary. There are various which are related to the aspects of meaning such as: meaning relationship, synonyms, and translation. (e) Word formation. Word formation is one of the methods to develop the students' vocabulary. The English teachers are suggested to teach the common prefixes and suffixes: for example, if learners know the meaning of un-and-able, this will help them to guess the meaning of the words like substandard, ungrateful, and untranslatable.

\section{Testing Vocabulary}

Any various methods often used by teacher or researchers in testing vocabulary to learners. The activity is normally done by them to test learners' ability in mastering vocabulary (Notion, 1990:3).

a. Identification. Students' are able to give response orally or in written form to identify appropriate words based on the definition.

b. Multiple choices. Students are able to choose the right word of more than two words have been provided in test.

c. Matching. Words have been presented and description in the column is to match randomly, actually it is another test for multiply choice.

d. Checking. Students check some words are able to known or not, they are fully expected to write the definition of words.

\section{Scientific Approach}

\section{Insight of Scientific Approach}

The term of Scientific Approach consists of two words, namely, scientific and approach. Suhariyadi (2013:22) explains that The word 'scientific' which is derived from the word 'science' means"about or related to science or using its methods" or"based on or characterized by the methods and principles of science. In this 
context, scientific means that any work or result a person achieves must be accomplished by following the principles available in science. For example, when one generated scientific writing, she/he must have had understood and followed the principles of writing. Furthermore, a lot of words are intentionally combined with the word 'scientific' to create an academic image and reflect the principles of science such as 'scientific writing', scientific observation', scientific inquiry', scientific research', scientific knowledge', and 'scientific observation'.

Aspin (1995) in Wahyudin (2015:56) elucidates that originally a scientific approach is basically a common term used in the field of inquiry. It is from the empiricist theory that views experience as a foundation or source of knowledge. This view also gained support from a philosophy of science called positivism that believes the goal of knowledge is derived from logical and report of sensory experience of phenomena.

The opinion above is relevant to Smith (2003:27) that in positivist view of the world, science was seen as the way to get truth, to understand the world well enough so that the learners may predict and control it. Therefore, this believes that it gave rise to a method of finding the truth called scientific approach.

Related to the views above, the researcher may say that scientific approach is the way or process of getting truth based on the world phenomena, and learners' experience become a knowledge or source of knowledge.

\section{Criteria of Scientific Approach}

Suhariyadi (2013:22) explains that there are seven criteria to determine whether an approach of teaching and learning process is scientific or not. They are (1) the teaching materials are based on the facts or phenomena which can be logically or reasonable explained. They are not based on prediction, approximation, imagination, legend, or myth, (2) the teacher's explanation, students' responses, and teachersstudents interaction are not based on the subjectivity and wrong logic, (3) the teaching materials support and inspire students to be critical in thinking and analyzing and accurate in identifying, understanding, and resolving problems, and applying the materials learned, (4) the learning materials foster and inspire students to hypnotically think when seeing diversities, smiliraties, and links in the learning 
materials, (5) the learning materials foster and inspire students to understand, apply, and develop objectivity and rational thinking in responding to the learning materials, (6) the materials are built on the basis on empirically valid concept, theories, and facts, and (7) the formulation of learning objectives is simple, clear, and attractive.

\section{Steps Teaching and Learning in Scientific Approach}

According to Suhariyadi (2013:27), there are three points that become the focus in teaching and learning process with Scientific Aprproach. They include attitudes (affective), skills (psychomotor) and knowledge (cognitive). Attitudes refer "students know why", skills refer to "students know how", and knowledge refers to "what students know". These three points are expected to make students affective, creative innovative, and productive. In other words, with these three points, students have soft skills and hard skills to live properly. In order to achieve these goals, the teachers follow the five steps in teaching and learning process. They are observing, questioning, associating, experimenting, and networking. Each of the steps is presented in the following.

\section{Observing}

Observing is a kind of meaningful learning. Here, students and teachers are provided with objects, real objects, or phenomena. Students are directly involved in learning. It helps teachers to contextualize students' learning in the classroom. At the same time, students can learn based on what they see to construct their knowledge. It also facilitates students to fulfill their need of knowing something. In this context, their curiosity will lead them to the construction of knowledge. Contextually is also present because students can connect what they have learned with what they are going to learn.

\section{Questioning}

The second step is questioning. It is a powerful teaching technique that has been used for years since it was firstly introduced by Socrates. Research indicates that questioning is second only to lecturing in popularity as a teaching method and that classroom teachers spend anywhere from thirty-five to fifty percent of their instructional time conducting questioning sessions. Other findings show that (1) 
instruction which includes posing questions during lessons is more effective in producing achievement gains than instruction carried out without questioning students, (2) students perform better on test items previously asked as recitation questions than on items they have not been exposed to before, (3) oral questions posed during classroom recitations are more effective in fostering learning than are written questions, (4) questions which focus student attention on salient elements in the lesson result in better comprehension than questions which do not.

Questioning can be used by both teachers and students in the classroom. What are the purposes of teachers ${ }^{\text {ee }}$ classroom questions? A variety of purposes emerge from analysis of the literature, including (1) to develop interest and motivate students to become actively involved in lessons, (2) to evaluate students ${ }^{\text {ee }}$ preparation and check on homework or seatwork completion, (3) to develop critical thinking skills and inquiring attitudes, (4) to review and summarize previous lessons, (5) to nurture insights by exposing new relationships, (6) to assess achievement of instructional goals and objectives, and (7) to stimulate students to pursue knowledge on their own.

\section{Associating}

The term "associating" used in Curriculum 2013 is more appropriate than "reasoning". "Associating is to describe teachers and studentse active participation in the classroom. Thus, students must be more active and are given more opportunities in learning. Associating is the process of thinking logically and systematically over-the empirical facts that can be observed in the form of knowledge to obtain conclusions. In the context of learning, "associating" is focused on students "e learning activities. That is why; "associating" is used in Curriculum in 2013 because it adopts the ideas of associative learning theories.

The term "associating" refers to the ability to group diverse ideas and associate diverse events as experiences. When the experiences are stored in the brain, they will interact with the previous events or experiences. This process is called "associating". From the perspective of psychology, "associating" refers to the connection between conceptual or mental entities as a result of the similarity between the mind or proximity in space and time. According to the theory of 
association, the learning process will be managed effectively in if there is a direct interaction between teachers with learners. Interaction is done through stimulus and response (SR) .Thus, the basic principles of the learning process in this theory is an association, which is also known as the theory of stimulus-response (SR). Here, learners' learning process occurs slowly or gradually, not suddenly.

How can "Associating" be applied in the learning process? The followings are the activities the teachers can do. (1) Teachers prepare the learning materials in a form that is ready in accordance with the demands of the curriculum, (2) the main task of the teacher is to give a brief but clear instructions with accompanying examples either by themselves or by means of simulation, (3) the learning materials are arranged in a tiered or hierarchical starting from the simple to the complex, (4) results-oriented learning activities can be measured and observed, (5) every error must be corrected or repaired, (6) repetition and practice need to be done so that the desired behavior can become a habit, (7) evaluation or assessment is based on the behavior of a real or authentic, and (8) the teachers record all learners progress.

\section{Experimenting}

To get the real or authentic learning, learners have to do experiments. For example, students should understand the concepts of science and its relation to everyday life. Learners must have the skills to develop knowledge about the environment, and be able to use the scientific method and scientific attitude to solve the problems they face in everyday life. The application of experimental methods is intended to develop various learning objectives, the attitudes, skills, and knowledge.

\section{Networking}

Networking is also called collaborative learning. Here, collaborative learning is a personal philosophy, which is more than just learning techniques in the classrooms. Collaboration is the essence of philosophy and lifestyle of human interaction that places and facilitates collective efforts in order to achieve common goals. For teachers, the collaborative learning function is more directive oriented in which the teachers are managers in the students ${ }^{e e}$ learning. Here, the students are those who are active. In a collaborative situation, the learners interact with empathy, mutual 
respect, and receive a deficiency or excess, respectively. This allows the learners to face various changes and challenges to learn together.

\section{METHODOLOGY OF THE STUDY}

This study used pre-experimental design. The sample of this study was 30 students. The sample was taken by using purposive sampling technique. The instrument of this study was a vocabulary test. The test consisted of 40 items in multiple-choices, and matching form.

\section{Procedures of Teaching by Using Scientific Approach}

The procedures of teaching were as follows:

Pre-Activity

a. Before teaching students in every meeting by using scientific approach, the researcher did brain storming firstly, to stimulate students in learning and attracting their attention. For example, teacher gave some questions that related to the topic to check students' knowledge.

b. The teacher explained the aim of the study for the students.

c. The teacher showed the theme or topic of the words on the board and or on paper.

Main Activity

\section{Step 1 Observing}

a. The teacher provided reading text to students. The students read the text and observed and noted the bold words on the text.

b. The students observed the use of the bold words on the text based on the context.

\section{Step 2 Questioning}

a. The teacher asked the students to determine that bold words on the text by guessing the meaning based on the context.

b. Teacher asked students to pronounce the words

\section{Step 3 Associating}

a. Students answered the question what is the synonym and the antonym of the bold words on the text.

\section{Step 4 Experimenting}

a. Students made another sentences based on the bold words on the text. 


\section{Step 5 Networking}

a. Each group did presentation of their result to the class forum.

\section{DISCUSSION AND FINDING}

\section{Description of Students' Vocabulary Achievement on Pre-test}

The discussion of students' vocabulary achievement on pre-test was measured by students' score at grade eight of SMP Muhammadiyah Kendari before using Scientific Approach in teaching and learning process of vocabulary. The students' score on pre-test shows that there was one student who got score six point seventyfive (6.75) and it is as the highest score, and there was also one student who got score three point seventy-five (3.75) and it is as the lowest score. Meanwhile, the mean score was five point ninety-nine (4.99). It means that the average of students' vocabulary achievement before using Scientific Approach in teaching vocabulary at the grade eighth SMP Muhammadiyah Kendari is in low category.

\section{Description of Students' Vocabulary Achievement on Post-test}

After scoring students' answer on post-test, the result shows that there were three students who got score eight point seventy-five (8.75) and it was as the highest score, and there were two students who got score six point double zero (6.00) and it was as the lowest score. Meanwhile, the mean score was seven point fifty-nine (7.59). It means that the average of students' vocabulary achievement is high category after using Scientific Approach.

\section{The Comparison of Students' Vocabulary before and after Teaching Vocabulary through Semantic Gradient Technique}

The proposing of comparison the students' vocabulary achievement on pre-test and post-test in this section was in order to know whether there is difference of students' vocabulary achievement before and after using Scientific Approach. The result showed that there were differences of students' vocabulary achievement between pre-test and post-test. The result showed that the students' vocabulary achievement on post-test is higher than students' vocabulary achievement on pre-test. It means that there is an improvement of students' vocabulary achievement after using Scientific Approach at the grade eight of SMP Muhammadiyah Kendari. In other words, the researcher may say that by using Scientific Approach can improve the 
students' vocabulary achievement at the grade eight of SMP Muammadiyah Kendari.

After computing the hypothesis testing, it was found that the value of t-test was 25.36. If it was consulted to the t-table at the significant level or $\alpha=0.05$ with the standard $1-1 / 2 \alpha=t_{0,975}$ and the degree of freedom (df) 30 found that t-table $=$ 2.04. This result showed that t-test was higher than t-table 2.04. Therefore, Ho is rejected and $\mathrm{H} 1$ is accepted. It means that there is a significant effect of using Scientific Approach to improve students' vocabulary achievement at grade eight of SMP Muhammadiyah Kendari. It can be also stated that students' vocabulary achievement that was taught by using Scientific Approach can improve students' vocabulary significantly.

\section{CONCLUSION AND RECOMENDATION}

\section{Conclusion}

Based on the findings of the study, the researcher concludes teaching vocabulary by using Scientific Approach improves students' vocabulary achievement at grade eight of SMP Muhammadiyah in academic year 2017/2018. The result of hypothesis testing which proves that $\mathrm{t}$-test $=25.36$ is higher than $\mathrm{t}$-table $=2.04$. It means that there is a significant effect of using Scientific Approach to improve students' vocabulary achievement at the grade eight of SMP Muhammadiyah Kendari.

\section{Recommendation for Further Researcher}

Based on the finding of the study, the researcher recommends that (1) The further researchers who want to conduct the same study are suggested to use different design in the same or different stage of subjects. (2) The Department of National Education which is termed Depdiknas are hoped to recommend the English teachers in order they use Scientific Approach for improving the students' English vocabulary. As English subject is one of national test subjects, it is important for teachers to increase students' vocabulary knowledge to help them pass nasional test. Therefore, the effort of increasing students' vocabulary knowledge is one of the efforts to increase the quality of education in Indonesia through the mastery of English subject. 


\section{BIBLIOGRAPHY}

Arikunto, S., 2003. Dasar-Dasar Evaluasi Pendidikan. Edited Revision. Jakarta. Bumi Aksara

Darsono, T., 1996. Dasar-Dasar Penelitian Pendidikan. Jakarta: Depdikbud.

Flanigan and Greenwood. 2007. Overlapping Vocabulary and Comprehension: Context Clues Complement Semantic Gradients. Boston: A Pearson Education Company.

Harmer, J., 1993 . The Practice of English Language Teaching. Essex: Longman Group UK Limited,. ISBN 0582-04656-4

Iskandar. 2008. Metodologi Penelitian Pendidikan dan Sosial (Kuantitatif dan Kualitatif). Jakarta: Gaung Persada Press.

Kasiani. 2007. Enriching Your Students'Vocabulary with Fun. Jakarta: Depdiknas.

McCarthy, M., 1992. Vocabulary. Oxford: Oxford University Press, ISBN 0-19437136-0

McKeown, \& Kucan. 2002. Teaching and Learning Vocabulary. Pretince Hall International (VK) ltd.

Mido. 2012. Using Pictures on students' vocabulary improvement at the Third Grade of SMP Muhammadiyah Kendari. Kendari, UMK: Unpublished Thesis.

Notion, R., 1990. Teaching and Learning vocabulary. New York: Victoria University of Willinton, Newbury House publisher.

Rianse, Usman and Abdi. 2009. Metodologi Penelitian Sosial dan Ekonomi: Teori dan Aplikasi. Bandung: Alfabeta Bandung

Richards, J., \& Rodgers, T., (2001). Approaches and Methods in Language Teaching. Cambridge: Cambridge: Cambridge University Press

Stahl, S., 2005. The Elements of Teaching Language. London: Clarendom Publisher.

Surachmnd. W. 1984. Pengantar Penilaian Pendidikan. Bandung: Angkasa.

Thornbury, S., 2004. How to Teach Vocabulary. Essex: Pearson Education Limited, 2004. ISBN 0582-429668

Tierney, R.J., \& Readence, J.E. 2000. Vocabulary strategies and practices: A Compendium (5th ed.). Boston: Allyn \& Bacon. 
Ur, Penny. 1996. A Course in Language Teaching. Cambridge. University press.

Usman, Mohammada Uzer. 2002. Menjadi Guru Profesional. Bandung: Rosda Karya.

Wardiman, Artono, et.al. 2008. Language in Focus" for Grade Nine Junior High School (SMP/MTs). Jakarta: Depdiknas. 